Sains Malaysiana 50(8)(2021): 2379-2393

http://doi.org/10.17576/jsm-2021-5008-20

\title{
Evaluating the Potential of Pyriproxyfen Dissemination using Mosquito Home System against Aedes albopictus at a Dengue Hotspot Area
}

(Menilai Potensi Penyebaran Pyriproxyfen menggunakan Sistem Rumah Nyamuk terhadap Aedes albopictus di Satu Kawasan 'Titik Panas’ Denggi)

\author{
Ahmad Mohiddin Mohd Ngesom, Nazni Wasi Ahmad, Lee Han Lim, Asmalia Md Lasim, David \\ GreENHALGH, MaZRURA SAHANi, Rozita Hod \& HidAYATUlFATHI OTHMAN*
}

\begin{abstract}
Aedes mosquitoes were found to lay their eggs in the cryptic breeding sites. Eliminating cryptic and open breeding sites is essential in reducing dengue virus transmission. However, it is often challenging for health officers to assess these breeding sites which are usually missed during larval surveillance. The autodissemination approach may produce a better outcome by manipulating female mosquitoes to disperse insecticide to other Aedes spp. mosquito habitats. Thus, the present study aims to evaluate the effectiveness of the pyriproxyfen autodissemination technique using Mosquito Home System against the population of mosquitoes. This study was conducted in Bandar Baru Bangi, Selangor, Malaysia. The Mosquito Home System was deployed to control Aedes spp. populations at treatment sites using before-aftercontrol-impact (BACI) design. The presence of pyriproxyfen distribution was confirmed using the WHO larval bioassay which resulted in 10-35\% larvae mortalities. Autodissemination of pyriproxyfen significantly reduced the population size of mosquito eggs $(p<0.05)$, larvae $(p<0.05)$, and ovitrap index $(p<0.05)$ at the treatment areas compared to the control areas. Moreover, rainfall was correlated positively against ovitrap index $(r=0.247)$, larvae $(r=0.420)$, and eggs $(r=0.422)$. The study provides promising results for controlling Aedes spp. populations and also highlights the potentials of this technique as an alternative in vector control programmes. However, further studies on larger scale field trials are warranted.
\end{abstract}

Keywords: Aedes; autodissemination; emergence inhibition; pyriproxyfen; vector control

\section{ABSTRAK}

Nyamuk Aedes ditemui bertelur di kawasan pembiakan yang tersembunyi. Penghapusan bekas tersembunyi dan terbuka adalah penting bagi mengurangkan penularan virus denggi. Walau bagaimanapun, kawasan pembiakan ini sukar dikesan oleh anggota kesihatan dan lazimnya diabaikan semasa pemantauan larva. Kaedah penyebaran-auto memberikan keputusan yang baik dengan memanipulasi nyamuk betina untuk memindahkan insektisid ke habitat nyamuk Aedes. Oleh itu, kajian ini adalah untuk menilai keberkesanan kaedah penyebaran-auto pyriproxyfen menggunakan Sistem Rumah Nyamuk terhadap populasi nyamuk liar. Kajian ini dijalankan di Bandar Baru Bangi, Selangor. Sistem Rumah Nyamuk digunakan untuk mengawal populasi Aedes spp. di lokasi rawatan dengan kaedah sebelum-selepas-kawalanimpak. Kehadiran penyebaran pyriproxyfen dibuktikan dengan bioasai larva WHO telah menunjukkan 10-35\% mortaliti larva. Penyebaran pyriproxyfen secara signifikan menurunkan saiz populasi telur nyamuk $(p<0.05)$, larva $(p<0.05)$ dan indeks ovitrap $(p<0.05)$ di kawasan rawatan berbanding kawasan kawalan. Selain itu, taburan hujan berkorelasi secara positif terhadap indeks ovitrap $(r=0.247)$, larva $(r=0.420)$ dan telur $(r=0.422)$. Kajian ini memberikan keputusan yang memberangsangkan dalam mengawal populasi Aedes spp. dan menyerlahkan potensi kaedah ini sebagai alternatif dalam program kawalan vektor. Walau bagaimanapun, kajian lapangan pada skala besar adalah satu keperluan.

Kata kunci: Aedes; kawalan vektor; penyebaran-auto; perencatan tumbesaran; pyriproxyfen 


\section{INTRODUCTION}

Dengue fever is one of the most common vector-borne diseases spreading across the world. It is estimated that more than 3.9 billion people from 129 countries are at risk of contracting dengue fever, with one million deaths reported each year (Bhatt et al. 2011; WHO 2020). The World Health Organization (WHO 2020) reported that the Asian region represents $70 \%$ of the global burden of dengue with several countries having become endemic including Cambodia (Ladien et al. 2019), Indonesia (Maula et al. 2018), Thailand (Srichan et al. 2018), Singapore (Ong et al. 2018), and Malaysia (Suppiah et al. 2018).

Aedes aegypti and Ae. albopictus play a vital role in the transmission of dengue, yellow fever and zika virus infection. Aedes aegypti is more competent and easily adapts to different environments in a short period compared to Ae. albopictus (Main et al. 2018). Both species are more likely to be near human habitats and are usually active in the early morning and late afternoon (Sahani et al. 2012). However, due to their anthropophilic nature (Raji et al. 2019), this species prefers to feed on human rather than animal blood, thus acting as the primary vector for the transmission of dengue virus.

Currently, there are no commercial vaccines and specific treatments for dengue infections. Thus, dengue fever mainly controlled by prevention through management system (Lindsay et al. 2017; Othman et al. 2017). However, vector control programme that rely on insecticide and surveilance activities might not be sufficient to control dengue transmission (Abu Hasan et al. 2017), perhaps due to insecticide resistance, expanding Ae. aegypti populations and lack of management strategies (Achee et al. 2015; Bowman et al. 2016). Therefore, the development of new alternative methods is necessary to overcome the spread of dengue and other mosquito-borne diseases (Buchman et al. 2019; Hidayatulfathi et al. 2017).

Autodissemination approaches using pyriproxyfen have been widely used in mosquito-borne diseases control. This method uses the concept of pulling (the ability to attract mosquitoes into autodissemination stations) and release (mosquitoes exposed to pyriproxyfen may spread the particles to other locations) to control mosquito populations in the field (Liang et al. 2019; Ngesom et al. 2020). This strategy has produced promising results by controlling various mosquito populations, including Ae. albopictus (Suman et al. 2018), Ae. japonicus (Tuten et al. 2016), An. arabiensi (Lwetoijera et al. 2019), and An. gambiae (Mbare et al. 2014) in both laboratory and field conditions.

Although these approaches have been successfully used in other countries, the implementation of this strategy is still in the early stages, and no detailed studies have been conducted in Malaysia to the best of our knowledge. Specifically, the purpose of this study is to evaluate the capabilities of the Mosquito Home System (MHS) to disperse pyriproxyfen to other breeding sites and subsequently reduce the population of mosquitoes.

\section{MATERIALS AND METHODS}

\section{RESEARCH AREA}

This study was conducted at Seksyen 4, Bandar Baru Bangi (2॰57'43.9” N, $101^{\circ} 46^{\prime} 40.8^{\prime \prime}$ E) covering three
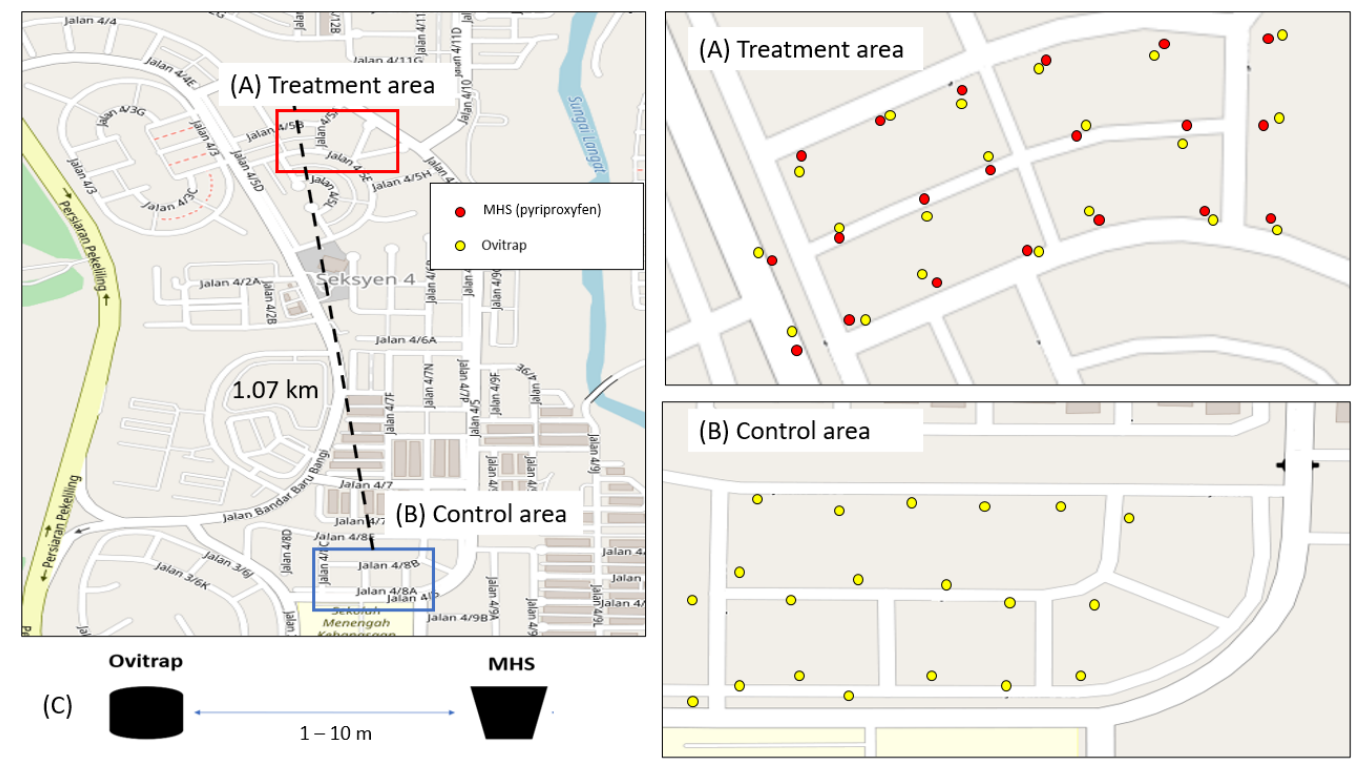

FIGURE 1. Study area at Seksyen 4, Bandar Baru Bangi (A) Treatment site consisted of a 20 placement point of Mosquito Home System (MHS: red circle), 20 placement point of ovitrap (ovitrap: yellow circle), (B) Control site consisted of a ovitrap without any MHS, and (C) Ovitrap were deployed in between 1-10 m interval with MHS 
main roads (Jalan 4/5a, Jalan 4/5b, and Jalan 4/5e) of a residential area with forty-two units of houses under a similar environment. The residential area at Jalan $4 / 8 \mathrm{a}$ and 4/8b (2॰57'06.3” N, 101 ${ }^{\circ} 46^{\prime} 50.2^{\prime \prime}$ E) was designed as a controlled location; with similar housing structures and the environment as the treatment location. This particular area have been dengue hotspots since 2010, and cases are still being reported from this area. There was no dengue vector control measure conducted during the trials. Both areas were seperated by a distance of 1.07 kilometres (Figure 1).

\section{AUTODISSEMINATION STATIONS}

The Mosquito Home System (hereafter referred as the MHS) trap used for this research is described elsewhere (Yazan et al. 2020). The MHS was made from black polyethylene $19.7 \mathrm{~cm}$ in height and $14.6 \mathrm{~cm}$ diameter at the top. It was rounded shape similar to a flowerpot with ten openings at the top. The MHS was filled with Mosquito Home Aqua (MHAQ) emulsifier formulations (0.004\% w/w of pyriproxyfen according to the manufacturer's recommendations) and $\mathrm{C}$-fold white paper towels were placed on the wall of the stations which served as oviposition substrate for mosquitoes (Figure 2). The oviposition substrate site was contaminated with MHAQ at half of the water level to act as a moistened surfaces and source of the pyriproxyfen (Panigrahi et al. 2014). Gravid female mosquitoes were deliberately exposed by tarsal contact with MHAQ solutions treated surfaces during oviposition and disseminated to other containers via 'skip oviposition' behavior. Mosquito Home System and MHAQ was supplied by One Team Networks Sdn. Bhd.
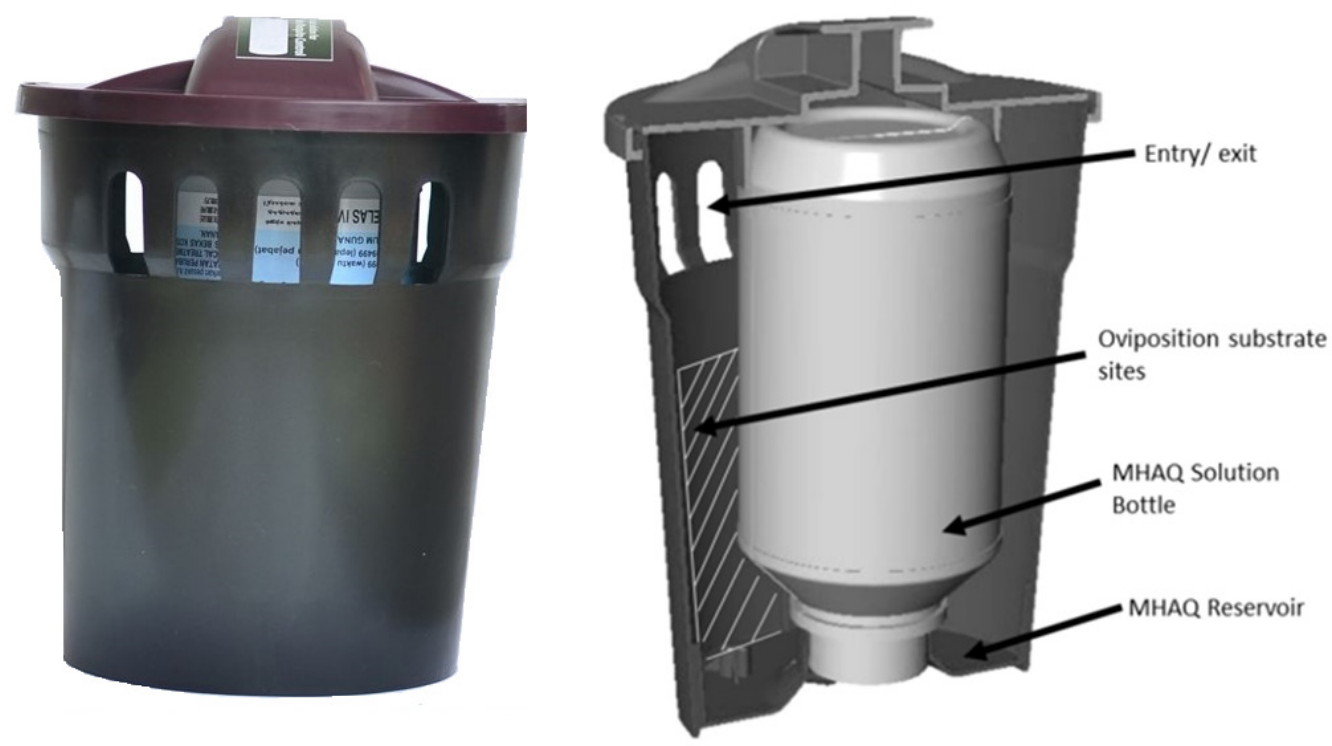

FIGURE 2. Mosquito Home System consisting of an oviposition substrate, MHAQ solution bottle and MHAQ reservoir

\section{STUDY PROCEDURES}

This study was conducted based on previous researches (Caputo et al. 2012; Suman et al. 2014) with several modifications; for 21 weeks from April to September 2018.
The study was conducted with longer period of testing by using pyriproxyfen in liquid form. It was divided into three phases; the pre-intervention phase (4 weeks), the intervention phase (13 weeks) and the post-intervention phase ( 4 weeks) based on before-after-control-impact 
(BACI) design (Smith et al. 1993; Stewart-Oaten \& Murdoch 1986). Initially, ovitraps were deployed in the treatment and control area until the end of the trials (Figure 1(A), 1(B)). The ovitraps were observed at weekly intervals and larvae were identified to species to determine the ratio of Aedes sp. In the second month, the MHSs were deployed to selected treatment areas for 13 weeks (Figure 1(A)). Following the intervention phase, MHS were placed around the ovitrap at distance interval range of 1-10 $\mathrm{m}$ within access of the Aedes population (Figure 1(C)). The larvae density and ratio of Aedes sp. were recorded continuously until the end of the trials. The impact of autodissemination in the field was assessed by monitoring the residual effect of MHAQ in water samples from each treatment and control area. The transference of MHAQ to other ovitraps by mosquitoes was detected by comparing the larval mortality in water samples collected from each treatment and control site via larval bioassay. The overall design of the study procedure is shown in Figure 3.

\section{MOSQUITO SURVEILLANCE}

The surveillance of mosquitoes was carried out using 120 ovitrap (60 in the treatment area, 60 in the control area) deployed randomly around the residential at ground level in the partially or totally shaded area to protect them from heavy rain, wind and direct sunlight (Chadee \& Ritchie 2010). Due to the skip oviposition behaviour exhibited in Aedes sp., three ovitrap were placed clustering at 20 placement points (one cluster with three ovitrap) at the treatment and control locations (Figure 1(A), 1(B)). The ovitraps are collected in five to seven days, and were replaced with a new set (Ahmad-Azri et al. 2019; Norzahira et al. 2011; VBD 2005). Each ovitrap and paddle collected from the treatment and control areas was taken to the laboratory separately to prevent any contamination. Number of eggs and larvae were counted and larval identification was performed under a binocular stereo microscope.

\section{INTERVENTION STUDIES}

In treatment sites, 20 placement point (40 MHS stations) were deployed around the residential area within $10 \mathrm{~m}$ intervals from each cluster of ovitraps. The MHS treatment was conducted for thirteen weeks from June 2018 (week five) to August 2018 (week 18); all MHSs were removed from the treatment areas at the end of week 18. No MHS were placed at the control area (Figure 1(A)). Mosquito Home Systems were serviced forthnightly in order to refill MHAQ solution and to replace any missing or broken units. Each MHS from the treatment area was observed and the number of eggs (in the oviposition substrate), larvae, and pupae were recorded in weekly basis. Meanwhile, water samples from the MHSs were collected at two weeks intervals after the first deployment. The recovered waters was transferred to a new cup and brought back to the laboratory for further evaluations (Figure 3).

\section{ASSESSMENT OF PYRIPROXYFEN AUTODISSEMINATION EFFICACY \\ MOSQUITO HOME SYSTEM}

The direct impact of pyriproxyfen was evaluated using larval bioassay from water samples collected from 20 placement points of MHS at 5, 7, 9, 11, 13, 15, and 17 weeks. Mosquito Home System were selected to obtained 50 to $200 \mathrm{~mL}$. In addition, water samples from MHS only available during intervention period.

\section{OVITRAP SURVEILLANCE}

The pyriproxyfen dispersal by Aedes spp. was assessed by monitoring the mortality or pupation of larvae exposed using the water samples collected from the treatment area (potentially contaminated with pyriproxyfen) and the control area. Water collected from 30 ovitrap (10 placement points) were tested at three different points in time, pre-intervention, intervention and post-intervention at every two weeks.

\section{MOSQUITO REARING}

Mosquito rearing and maintenance are described elsewhere (Imam et al. 2014). Larvae Ae. albopictus laboratory strain were obtained from a colony established in the Vector Control Research Unit (VCRU), Universiti Sains Malaysia. Filter paper with eggs were submerged into seasoned tap water and hatched larvae were transferred to an enamel pan containing $1 \mathrm{~L}$ of seasoned tap water and $100 \mathrm{mg}$ of Tetramin ${ }^{\circledR}$ Baby fish as food for larvae. All pupae were transferred in a plastic cup and placed in a mosquito rearing cage, and provided with cotton soaked in $10 \%$ sucrose. Female mosquitoes were solely bloodfed on guinea pig and eggs were collected on 
filter paper. The third instar of $\mathrm{F}_{1}$ and $\mathrm{F}_{2}$ generation larvae mosquitoes were used in all bioassays. Insectaries were maintained at temperature of $26 \pm 2{ }^{\circ} \mathrm{C}$ and $60 \pm 20 \% \mathrm{RH}$ and preferably a photoperiod of $12 \mathrm{~h}$ light followed by $12 \mathrm{~h}$ dark.

\section{LARVAL BIOASSAYS}

Water samples collected from 30 ovitraps from each site and MHSs were brought back to the laboratory for the assessment of auto-dissemination activiy. Those samples were filtered to remove organic debris and wild mosquito populations. Twenty laboratory-reared third instar Ae. albopictus larvae were exposed to $50-200 \mathrm{~mL}$ field water samples following larval bioassay procedure as described by the WHO (2016). For the laboratory control, three cups were set up using tap water and 20 larvae per bioassay. The percentage of larval mortality was recorded every $24 \mathrm{~h}$ and pupal mortality, abnormal morphology or coloration were observed until the larvae (control) reached adulthood or died. Experiments were conducted at temperature of $26 \pm 2{ }^{\circ} \mathrm{C}$ and $60 \pm 20 \% \mathrm{RH}$ and preferably a photoperiod of $12 \mathrm{~h}$ light followed by $12 \mathrm{~h}$ dark. Each treatment was replicated three times (depending the volume of water collected from MHSs and ovitraps) and the complete assays were repeated every two weeks until the end of the trials. In certain circumstances, some bioassay had to be conducted using single replicate as the amount of water collected was too low.

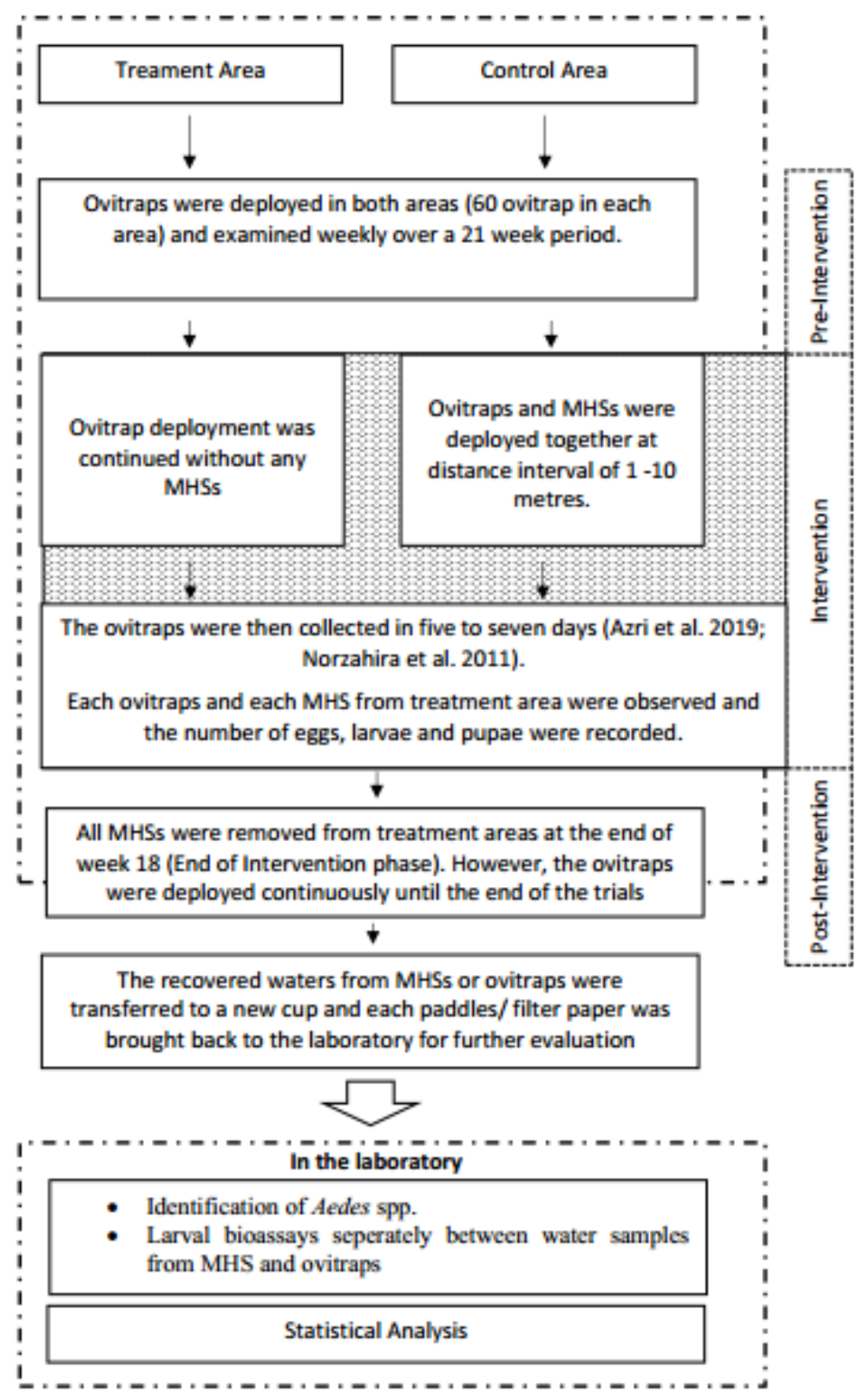

FIGURE 3. Flowchart of the study procedure 


\section{METEOROLOGY DATA}

Meteorological data including rainfall distribution, relative humidity and temperature were obtained from the Malaysian Meteorological Department. Data collection was conducted from April to September 2018.

\section{STATISTICAL ANALYSIS}

The abundance level of mosquito populations was evaluated using a positive ovitrap index. The average value of eggs per container was keyed into the Microsoft Office Excel file. The mean number of larvae was compared by a non-parametric Mann-Whitney-U-test. The relationship between meteorological parameters and population size of Aedes spp. such as the average numbers of eggs collected at the autodissemination station, the number of eggs and larvae from the treatment and control locations as well as the ovitrap index was analysed using Pearson's Correlation. A paired $t$-test analysis was used to determine the differences between larval and egg populations in the control and treatment areas (Afify et al. 2014). The paired BACI approach was found to be a powerful analytic tool for comparing any changes in treatment areas with control areas. All statistical analyses were conducted using Statistical Package for the Social Science (SPSS) version 23.0.

\section{RESUlTS AND DISCUSSION}

A total of 19,676 mosquito larvae were recorded from treatment locations at Seksyen 4, Bandar Baru Bangi throughout the study (21 weeks). The collection showed that $97.07 \%$ of larvae were Ae. albopictus species whilst the remaining larvae were Ae. aegypti (2.93\%). Additionally the Ae. albopictus species significantly the highest proportion $(93.76 \%)$ found in both controlled ( $U$ $=0.000 ; Z=-5.548 ; P=0.000)$ and treatment locations $(U=0.000 ; Z=-5.550 ; P=0.000)($ Figure 4$)$.

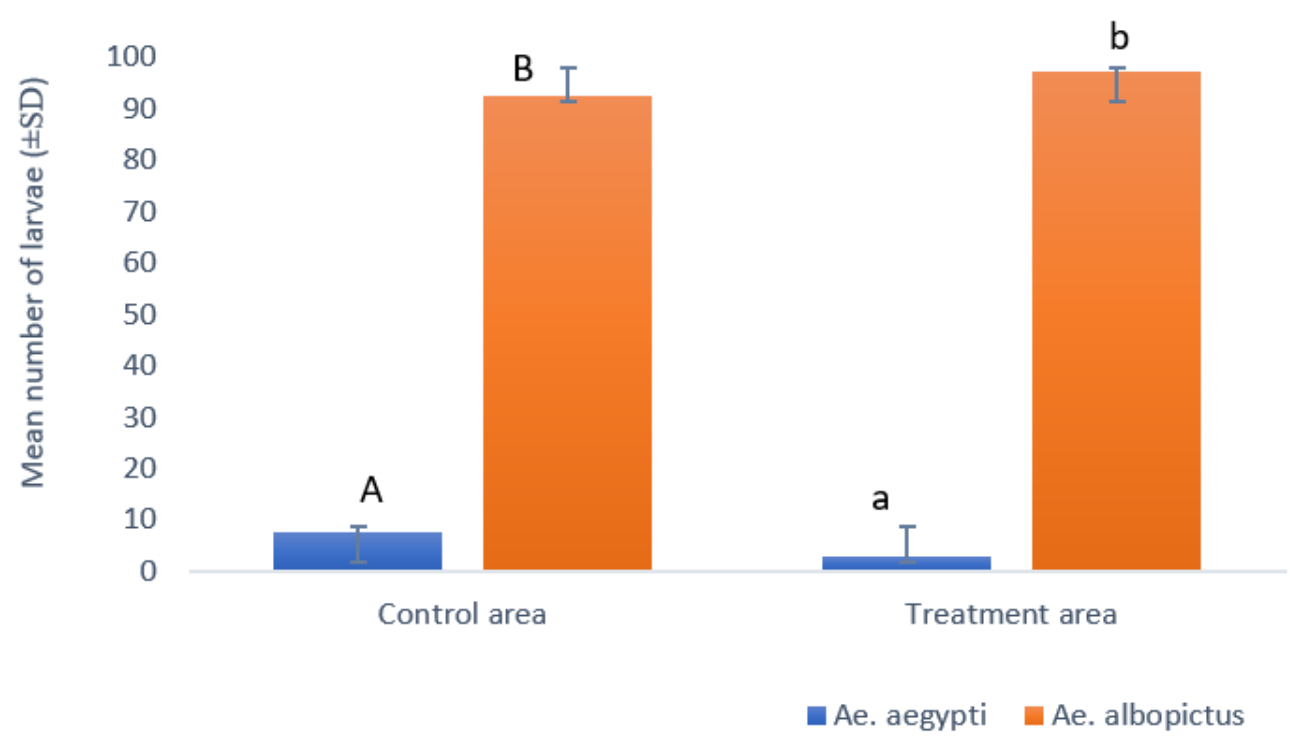

FIGURE 4. No of larvae collected (mean $\pm \mathrm{SD}$ ) of Ae. aegypti (blue bars) and Ae. albopictus (orange bar) in control (Mann-Whitney- $U, p=0.000$ ) and treatment sites (Mann-Whitney- $U, p=0.000$ ). Different letters above bars indicate the significant differences between Ae. aegypti and Ae. albopictus in each treatment and control area 
During the study period, a trimodal pattern of mean number of larvae was observed to increase gradually from the first weeks until the fifth weeks. The values then decreased until week seven and subsequently more or less increased until week 12. Moreover, the frequency of the larvae were steadily and parallel to the increase in Aedes sp. larvae populations (weeks 13 - 21). In the meantime, the average rainfall was $71.32 \mathrm{~mm}(\mathrm{SE}=10.51$; $95 \mathrm{Cl} ; 49.963,92.693)$ and the average temperature $27.67{ }^{\circ} \mathrm{C}(\mathrm{SE}=0.413 ; 95 \mathrm{Cl} ; 26.832,28.515)$. The highest rainfall was recorded in week four $(28.5 \mathrm{~mm})$; in weeks 6,11 and 15 the lowest rainfall was recorded. The temperature showed a stable fluctuations ranging from 23.5 to $30.1{ }^{\circ} \mathrm{C}$ (Figure 5).

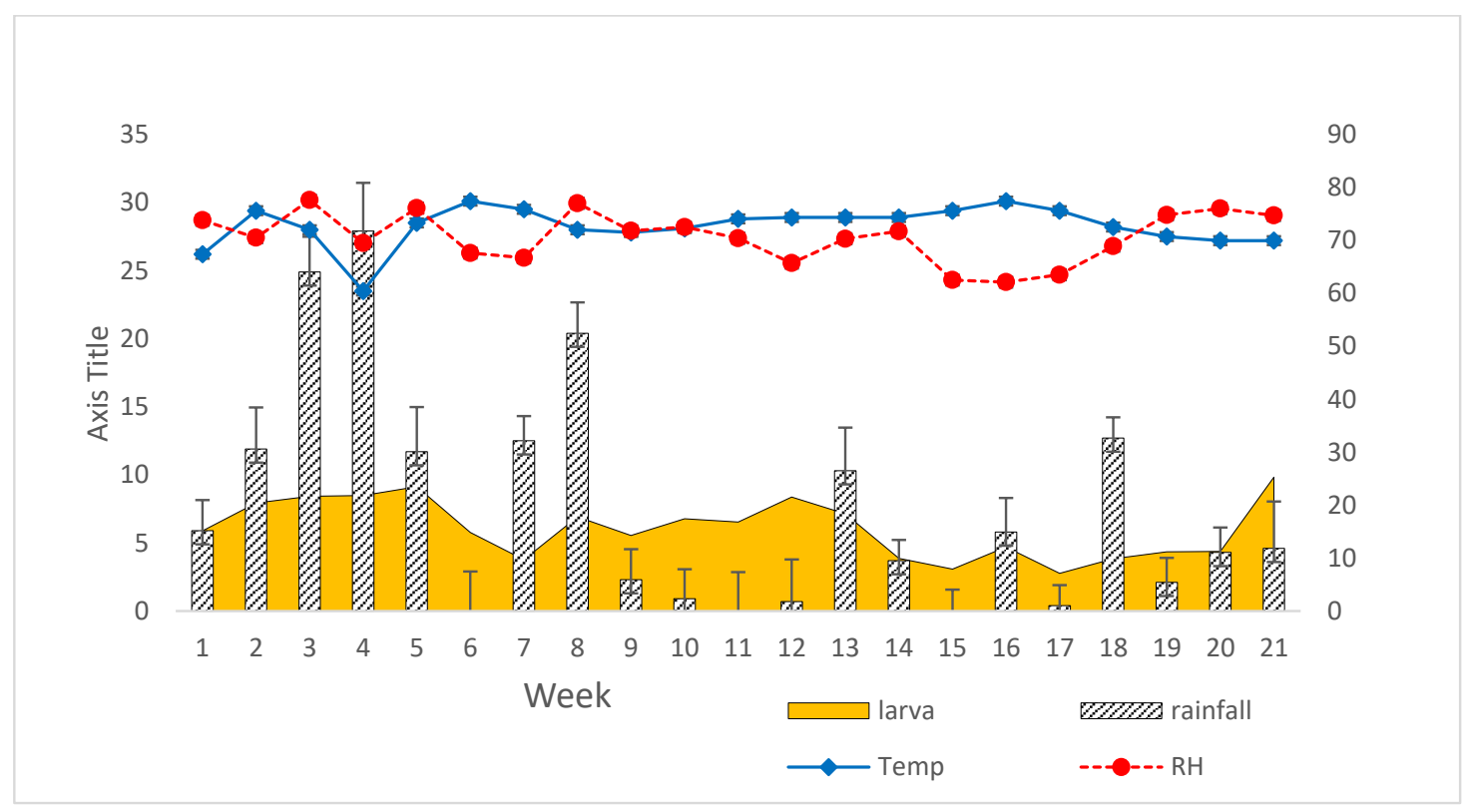

FIGURE 5. Temporal variation of weekly rainfall (patterned bars), mean number of Aedes spp. larvae (yellow area), relative humidity (red line) and mean temperature (blue line) at Bandar Baru Bangi

In this study, ovitraps were installed at control and treatment sites weekly to obtain baseline data related to the area (mosquito abundance and density). As the number of dengue cases reported in Malaysia is increasing, it is very important to determine the mosquitoes population species that play a crucial role in the transmission of dengue diseases. In a suburban area of Merida City, Ae. albopictus was first reported in artificial containers, at a trash collection point with improper was management, and in an abandoned area which was covered with vegetation (Contreras-Perera et al. 2019). Rozilawati et al. (2007) also found that the Ae. albopictus was the most prevalent species in the suburban areas. However, both Ae. aegypti and Ae. albopictus can be found indoors and outdoors, although Ae. aegypti is strictly domilicary, preferring to rest, biting, mate and oviposit indoors, while Ae. albopictus is more exhopagic and breeds in a natural containers. The high numbers of Ae. albopictus obtained 
in this study might explained by the fact that the ovitraps were mainly placed in outdoor locations.

Both Ae. aegypti and Ae. albopictus exhibit skip oviposition behavior, in other words the species may find several breeding containers in which to lay their eggs. Thus, we can study any mosquito species that inhabits a given area with a view to exposing the mosquito to pyriproxyfen which will subsequently be transferred to other breeding sites. Other findings found that both Ae. aegypti and Ae. albopictus are equally efficient in transferring priproxyfen with $95-100 \%$ reduction in mosquito populations. Moreover, the autodissemination strategy has been shown to significantly reduce mosquito populations but has several potential problems, in particular it works well in high mosquito population densities but not in a low ones and also encounters difficulties in extreme weather conditions and at extreme vector to host ratio. Moreover, the exact amount of autodissemination station required in each localities, the maintainance costs and the long-term efficacy of this technique still need to be explored (Pleydell \& Bouyer 2019).

\section{PYRIPROXYFEN DISSEMINATION EFFICACY MOSQUITO HOME SYSTEM}

The WHO larval bioassay was conducted using a water samples collected from MHS stations which showed 100\% mortalities of larvae after $24 \mathrm{~h}$ exposure; and therefore, no survival larvae were recorded from the MHS station (Figure 6). Even after two weeks from the pyriproxyfen replacement, MHAQ still retained a high level of efficacy with $100 \%$ pupal mortality.

\section{OVITRAP SURVEILLANCE}

The autodissemination activity of pyriproxyfen was evaluated based on larval bioassay on samples of water collected from ten placement point of the ovitrap. The mortality of the larvae was $15 \%$ at the beginning of week 13 , increasing to $35 \%$ week 15 and then decreasing to $10 \%$ in week 17 . Moreover, there is no pupal mortality was recorded from the water samples collected from the treatment area in the pre-intervention and postintervention periods (Figure 6). Thus, no pupal mortality was also reported from the water samples collected at control areas througout the study periods. In addition, there is a negative correlation between the mortality of larvae from the ovitrap with ovitrap index (percentage positive) $(r=-0.953)$, number of eggs $(r=-0.161)$ and larvae $(r=-0.407)$ (Figure 6).

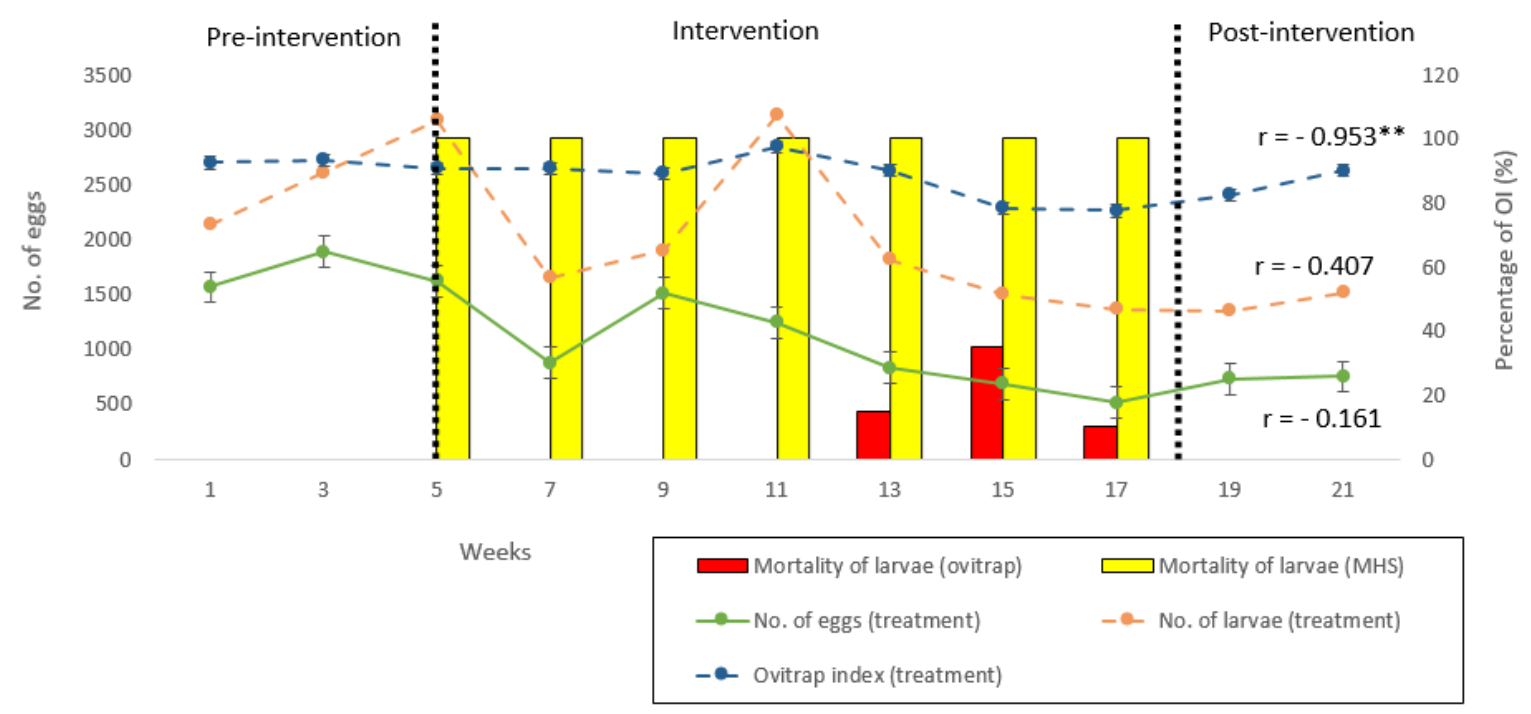

FIGURE 6. Correlation analysis between mortality of larvae from the ovitrap with number of eggs, ovitrap index (percentage positive) and numbers of larvae collected from the ovitrap in the treatment site for 21 weeks. Before-intervention / interventionpost treatments are indicated by dotted line. ${ }^{* *} p<0.001$ 
Based on the findings by Chism and Apperson (2003), the amount of pupal mortality may have an association with the time it takes the mosquitoes to lay eggs. The longer the time it took for mosquitoes to lay their eggs (egg number should be high), the higher the amount of pyriproxyfen carried and transferred to other containers, thus, increasing pupal mortality rate. A good relationship was obtained from various field trials with the percentage of pupal mortality and the percentage of sentinel contamination being positively correlated ( $r$ $=0.6$ ) (Suman et al. 2018). However, these result are contradictory and seems like other factors might influence the mortality of the larvae. It is important to investigate this and further study needs to be done to understand the transference process mechanism.

The effect of pyriproxyfen are a dose-dependent and inhibit mosquitoes development, morphological processes, embryogenesis, and reproductive system by different levels of dosage (Invest et al. 2008; Khan et al. 2016; Lau et al. 2015). Current findings report that pyriproxyfen can be transferred to other containers with overall supression around $12-19 \%$. However, the result vary with the time and place of the study (Unlu et al. 2020). Other field trials were conducted at the city of Manaus, Brazil with higher pupal mortality reaching $100 \%$ which is consistent with other studies: up to $100 \%$ (Abad-Franch et al. 2015), 14-53\% (Llyod et al. 2017), 50$70 \%$ (Caputo et al. 2012) and 70-100\% of pupal mortality (Unlu et al. 2017). These results were higher compared to our study probably due to the different day lengths, formulation of the pyriproxyfen (powder, oil or liquid) and the number competiting oviposites in the environment.
Moreover, other studies also found that the effectiveness of pyriproxyfen was reduced in within the times and can be influenced by various factors and substrates used (Suman et al. 2014). Besides that, the solution used (MHAQ) in this study was replenished every two weeks which might explain the effectiveness of its killing effect againt mosquito larvae.

\section{IMPACT OF MHS AND OVITRAP ON MOSQUITO POPULATIONS}

Based on BACI analysis, the reduction in larvae, eggs, and ovitrap index was significant $(p<0.05)$ when comparing pre-treatment with the post-treatment periods (Figure 7). In the early stages of the study, before the intervention there was no significant difference in egg populations between the control and treatment sites. This indicates that both populations had approximately equal numbers of eggs and larvae at each study site. The graph shows fluctuations in the number of eggs and larvae from week 4 to week 11. However, there was a consistent declining trend in both egg and larvae populations from week 12 to week 17/18 prior to a slight improvement in the following week. Significant differences were recorded in the number of eggs between the control and treatment sites ( $p=0.01$, paired $t$-test, $n=13$ ) and the number of larvae between the control and treatment sites ( $p$ $<0.05$, paired $t$-test, $n=13$ ). In contrast, after the MHS was removed from the treatment site, there was no significant difference shown between the sampling locations for either the number of egg $(\mathrm{p}=0.761$, paired $t$-test, $\mathrm{n}=4)$ or larvae $(\mathrm{p}=0.654$, paired $t$-test, $\mathrm{n}=4)$.

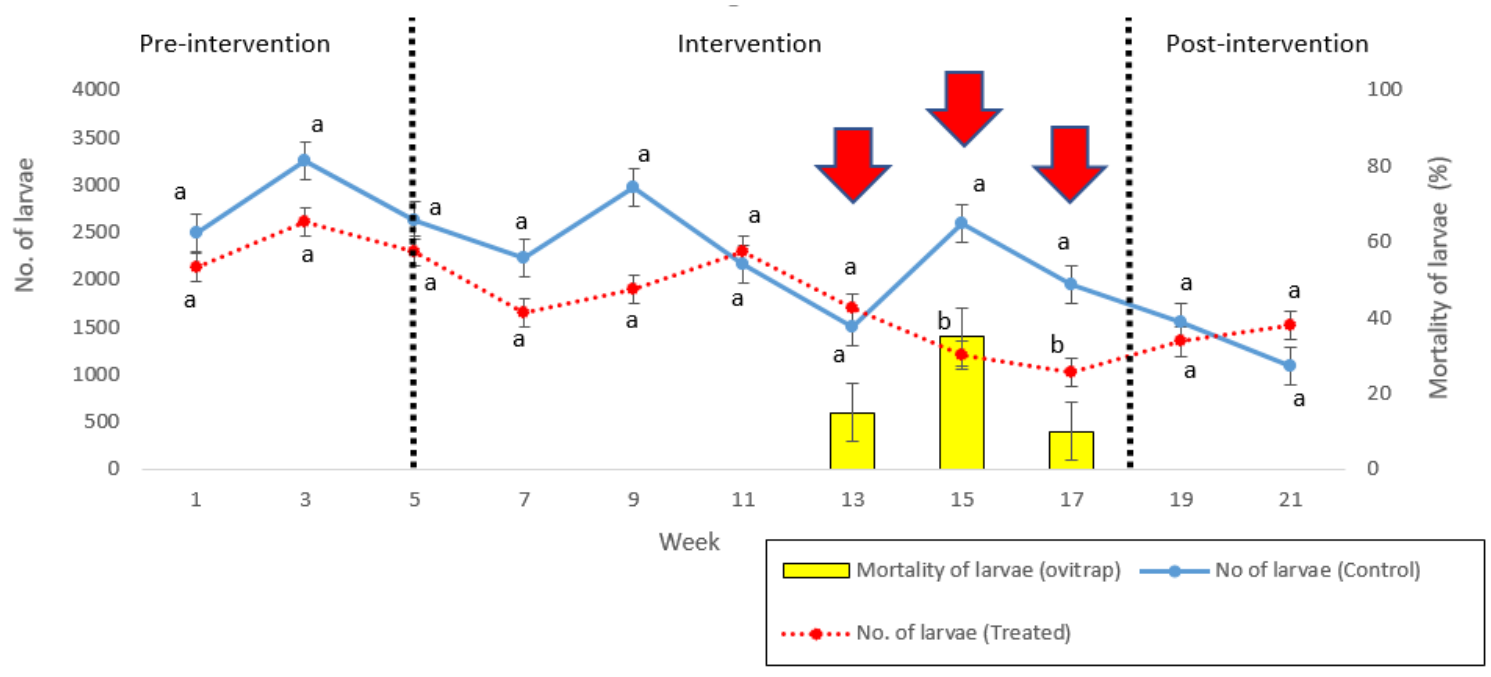

FIGURE 7. Weekly abundance of larvae Aedes mosquitoes collected by ovitrap surveillance in comparison during pre-treatment, treament and post-treatment periods in the treatment and control sites. The pre-treament, treatment, and post treatment time periods are separated by vertical black dotted line. The red arrows line indicate the presence of pyriproxyfen in the ovitraps containers which successfully killed the larvae. Different letters indicate statistically significant differences at $p<0.01$ between the control and treatment area 
This study has proven the effectiveness of the MHS as an autodissemination station by transferring pyriproxyfen particles from the MHS to the ovitrap, although the efficacy was low and varied throughout the trials. Larval bioassay was conducted to determine efficacy in the MHS, and in the ovitrap as well due to the potential of the MHS to be a source for dissemination of pyriproxyfen. Direct samples collected from the MHS using MHAQ formulations yielded promising results with $100 \%$ larvae mortality (Figure 5). The results indicate that pyriproxyfen significantly reduced the larvae population by inhibiting the egg production and causing death in immature larvae (Ohba et al. 2013).

Although the MHS stations were deployed starting from week five, there was no presence of pyriproxyfen observed until the $13^{\text {th }}$ week; the mortalities of larvae were observed in water samples collected from the ovitrap using larval bioassays. In the present study, larval mortality was inconsistent at week 13, 15, and 17 with higher larval mortality reported in week 15 (Figure $6)$. This situation indicated that the mosquitoes took a considerable amount of time to disperse pyriproxyfen particles to other breeding containers. This is likely due to the choice competition between the natural containers in the residential areas, which reduces mosquito tendency to lay eggs in the treatment container (Sithiprasasna et al. 2013). Residential areas may contain various plants and sources for mosquitoe breeding. Waste containers such as plastic containers, cups, roofs, and poultry containers may also become potential breeding sites.

Currently, Malaysian vector control strategies still rely on conventional methods that focus on thermal fogging, ultra-low volume spraying, larviciding, source reduction, and enforcement activities (Pang et al. 2017). Although thermal fogging eliminates adult mosquitoes, their offspring are still viable elsewhere in the breeding sites. The particles of insecticide were unable to penetrate into the cryptic or hidden areas such as closets or under the beds, thereby enabling the larvae to survive. Several findings found the inefficiency of space spraying in vector control management and that should be combined with others vector control techniques. Tee et al. (2019) found that one of the biggest issues in space spraying is the shortage of personnel. All premises must be checked within $200 \mathrm{~m}$ of index case and a large number of workers were expected to cover at least $200 \mathrm{~m}$ during fogging activities.
Since dengue cases have been registered on a regular basis, they need to prioritize all dengue localities which creates a backlog in some places and treatment are often missed. To ensure the effectiveness of the activities, all activities such as space spraying, ULV fogging, search and destroy larviciding must be performed simultaneously. However, other factors such as meteorological factors, vector control activities and human activities should be taken into account, and should be incorporated into dengue outbreak control programs.

As far as we are concerned, the OI is the best parameter for describing the Aedes population in the field (Sahani et al. 2012). This index was used under the guidelines of the Ministry Health, Malaysia to identify appropriate strategies and actions against each level of the OI. It was proposed that OI should be below a threshold values $(10 \%)$ and that all preventive measures be activated if the OI reaches $30 \%$. The presence of various factors such labor shortages, transportation and the high frequency of dengue cases, limited our ability to investigate a broader aspect of the local mosquito population. In addition, information on egg data and the adult population can also play an important role in expanding coverage in the vector control programme but is not practically used at the operational level (VBDS 2005). Moreover, previous studies found no correlation between the number of eggs and the adult population at treatment and control sites (Suter et al. 2016; Unlu et al. 2018).

Autodissemination of pyriproxyfen approach has become one of the most interesting methods to combine with other vector control strategies. The effectiveness of autodissemination relies highly on Aedes sp. working as transportation to disseminate insecticide to other cryptic breeding sites, in compliance with their 'skip-oviposition' behaviour (Lloyd et al. 2017; Mains et al. 2015). The application of autodissemination techniques increased the effectiveness of vector control program while reducing cost, time and labor compared to the previous Aedes spp. surveillance routine (Unlu et al. 2017). Other than that, mosquito exposed to pyriproxyfen were much more effective in finding cryptic breeding sites than humans. New paradigms in vector control are needed on the basis of these issues. An effective control measure against Aedes sp. mosquitoes is needed and we require to explicitly target adult, larvae, and cryptic breeding habitats for mosquitoes. 


\section{IMPACT OF METEOROLOGICAL FACTORS ON MOSQUITO POPULATIONS}

Temporal variation in meteorological data at Bandar Baru Bangi is indicated in Figure 5. The relationships between meteorological factors and entomological parameters were analysed using Pearson's correlation analysis and did not showed any significant correlation $(p>0.05)$. As well as there was a positive relationship between relative humidity denoted and the entomological data. For temperature data a positive relationship was observed with three other variables (number of larvae, number of eggs, and number of eggs collected from the MHSs), but a negative correlation was observed with the ovitrap index $(r=0.152)$. Rainfall was positively correlated with ovitrap index, number of larvae and number of eggs but not with the number of egg collected from MHS $(r=-0.119)$ (Table 1).

TABLE 1. Pearson's correlation analysis ( $r$ - correlation coefficient) between meteorological parameters and entomological data from ovitrap surveillance and MHS at treatment areas in 21 weeks

\begin{tabular}{|c|c|c|c|c|}
\hline \multirow{2}{*}{$\begin{array}{l}\text { Meteorological } \\
\text { parameters }\end{array}$} & \multicolumn{4}{|c|}{ Entomological data } \\
\hline & Ovitrap index & No. Larvae & No. eggs & No. eggs (MHS) \\
\hline Rainfall & 0.247 & 0.420 & 0.422 & -0.119 \\
\hline Temperature & -0.152 & 0.066 & 0.127 & 0.447 \\
\hline Relative humidity & 0.084 & 0.324 & 0.398 & 0.160 \\
\hline
\end{tabular}

Overall, meteorological factors are considered as some of the environmental factors for the risk affecting mosquito populations since they influence the mosquito survival. In this study, rainfall shows a moderate degree of correlation may play an important factor affecting the entomological pattern of mosquito abundance in the treatment area. Meanwhile, low correlation have been showed between temperature and relative humidity. Most of the entomological factors increased with the increasing in rainfall. A similar pattern has been found when using ovitrap (Rozilawati et al. 2007), egg count (Serpa et al. 2013) and house index (Withanage et al. 2020). A study in Central Nigeria reported that higher densities of mosquitoes were collected in the wet season compared to the dry season (Amaechi et al. 2018). The increase in rainfall may influence the number of egg and larvae (Hod et al. 2013). It is thought that increased rainfall may affected the amount of water in containers which may potentially serve as breeding sites for Aedes spp. mosquito, thus, making the condition more ideal and suitable for mosquitoes (Betanzos-Reyes et al. 2018). This situation may provide more breeding opportunities and subsequently prevent the mosquitoes from ovipositing inside the MHSs and ovitraps. Other than that, Suman et al. (2018) found that the concentrations of pyriproxyfen delivered were diluted from the autodissemination stations during the high rainfall. The pyriproxyfen solution was flushed out and reduced the pupal mortality and site contamination (Suman et al. 2017). Choi et al. (2016) found that the location of a region might possibly influence the differences in the interaction between rainfall and mosquito breeding sites, but such interaction can also be one of the model frameworks that provide early warning to the presence of dengue cases (Choi et al. 2016). 
However, heavy and continuous rainfall has been linked to a reduction in adult mosquito population due to the washing away of immature stage of mosquitoes.

We believe that climatic factors may also contribute to changes in epidemiological transmission of diseases related to mosquito population dynamics (Zul-Izzat et al. 2019), egg viability, larval development, and adult dispersal, while rainfall affects mosquito productivity and abundance of species (Tokachil et al. 2018; Valdez et al. 2018). Although each factor individually affects the biological system of Aedes mosquitoes, interaction between different factors will have a significant impact on the final proportion of mosquitoes (Azhar et al. 2016; Zapletal et al. 2018). Furthermore, our results suggest that both temperature and rainfall are more likely to contribute to additional changes in mosquito populations and possible habitat expansion for urban mosquitoes (Othman et al. 2019).

\section{CONCLUSION}

This study has proven the transfer of pyriproxyfen by wild Aedes spp. mosquitoes; by mortality of larvae during larva bioassays and by significant reduction of the population of Aedes spp. in the treatment location. The application of the MHS and pyriproxyfen demonstrated excellent potential to be used as an alternative tool in vector control. It is essential to assess the minimum number of MHSs needed to provide optimum autodissemination results. As the use of insect growth regulator can interfere with public health enforcement activities, the development of the MHAQ product has to be more effective than commercial larvicide. Therefore, further studies need to be conducted to improve the effectiveness of formulation as well as to prove the concept under largescale settings.

\section{ACKNOWLEDGEMENTS}

We wish to thank One Team Networks Sdn Bhd for providing the pyriproxyfen and Mosquito Home System used in this study. We also wish to thank Ms. Rawaida and Ms. Siti Rahayu for field sampling. We are grateful to Dr. Vanitha Mariappan and David Greenhalgh for proofreading of the manuscript.

\section{REFERENCES}

Abad-Franch, F., Zamora-Perea, E., Ferraz, G., PadillaTorres, S.D. \& Luz, S.L.B. 2015. Mosquito-disseminated pyriproxyfen yields high breeding-sit coverage and boosts juvenile mosquito mortality at the neighbourhood scale. PLoS Negl. Trop. Dis. 9(4): e0003702.

Abu Hasan, Z., Williams, H., Ismail, N.M., Othman, H., Cozier, G.E. \& Acharya, K.R. 2017. The toxicity of angiotensinconverting enzyme inhibitors to larvae of the disease vectors Aedes aegypti and Anopheles gambiae. Scientific Reports 7: 45409.

Achee, N.L., Gould, F., Perkins, T.A., Reiner, R.C., Morrison, A.C., Ritchie, S.A., Gubler, D.J., Teyssou, R. \& Scott, T.W. 2015. A critical assessment of vector control for dengue prevention. PLoS Neglected Tropical Diseases 9(5): $\mathrm{e} 0003655$.

Afify, A., Horlacher, B., Roller, J. \& Galizia, C.G. 2014. Different repellents for Aedes aegypti against blood-feeding and oviposition. PLoS ONE 9(7): e103765.

Ahmad-Azri, M., Syamsa, R.A., Ahmad-Firdaus, M.S. \& Aishah-Hani, A. 2019. A comparison to different types of ovitraps for outdoor monitoring of Aedes mosquitoes in Kuala Lumpur. Tropical Biomedicine 36(2): 335-347.

Amaechi, E.C., Ukpai, O.M., Ohaeri, C.C., Ejike, U.B. \& IroleEze, O.P. 2018. Distribution and seasonal abundance of anopheline mosquitoes and their association with rainfall around irigation and non-irrigation areas in Nigeria. Cuadernos de Investigación 10(2): 267-272.

Azhar, Z.I., Jusoh, A., Syed Abdul Rahim, S.S., Hassan, M.R., Safian, N. \& Shah, S.A. 2016. Temporal spatial distribution of dengue and implications on control in Hulu Langat, Selangor, Malaysia. Dengue Bull. 39: 19-31.

Betanzos-Reyes, A.F., Rodriguez, M.H., Romerp-Martinez, M., Sesma-Medrano, E., Rangel-Flores, H. \& Santos-Luna, R. 2018. Association with Aedes spp. abundance and climatological effects. Salud Pública de México 60(1): $12-20$.

Bhatt, S., Gething, P.W., Brady, O.J., Messina, J.P., Farlow, A.W. \& Moyes, C.L. 2011. The global distribution and burden dengue. Nature 496(7446): 504-507.

Bowman, L.R., Dobegan, S. \& McCall, P.J. 2016. Is dengue vector control deficient in effectiveness of evidence?: Systematic review and meta-analysis. PLoS Neglected Tropical Diseases 10(3): e0004551.

Buchman, A., Gamez, S., Li, M., Antosheckin, I., Li, H.H. \& Wang, H.W. 2019. Engineered resistance to zika virus in transgenic Aedes aegypti expressing a polycistronic cluster of synthetic small RNAs. PNAS 116(9): 3656-3661.

Caputo, B., Lenco, A., Cianci, D., Pombi, M., Petrarca, V. \& Baseggio, A. 2012. The autodissemination approach: A novel concept to fight Aedes albopictus in urban areas. PLoS Neglected Tropical Diseases 6(8): e1793.

Chadee, D.D. \& Ritchie, S.A. 2010. Efficacy of sticky and standard ovitraps for Aedes aegypti in Trinidad, Wes Indies. Journal of Vector Ecology 35(2): 395-400.

Chism, B.D. \& Apperson, C.S. 2003. Horizontal transfer of insect growth regulator pyriproxyfen to larval microcosm 
by gravid Aedes albopictus and Ochlerotatus triseriatus mosquitoes in the laboratory. Medical and Veterinary Entomology 17(2): 211-220.

Choi, Y., Tang, C.S., Mclver, L., Hashizume, M., Chan, V. \& Abeyasinghe, R.R. 2016. Effects of weather factors on dengue fever incidence and implication for interventions in Cambodia. BMC Public Health 16: 241.

Contreras-Perera, Y.J., Briceno-Mendez, M., Flores-Suares, A.E., Manrique-Saide, P. \& Palacio-Vargas, J.A. 2019. New record of Aedes albopictus in a suburban area of Merida, Yucatan, Mexico. Journal of the American Mosquito Control Association 35(3): 210-213.

Hidayatulfathi, O., Shamsuddin, A.F., Rajab, N.F., Nor Zafirah, A.B., Nur Hazwani, A.A. \& Nur Afriza, M.F.O. 2017. Three repellent gels that contain essential oils from local Malaysian plants against dengue vector. Tropical Biomedicine 34(3): 540-549.

Hod, R., Othman, H., Jemian, N.A., Sahani, M., Udin, M.K. \& Ali, Z.M. 2013. The COMBI approach in managing dengue cases in non urban residential area, Nilai, Malaysia. International Journal of Public Health Research 3(2): $347-$ 352.

Imam, H., Zarnigar, Sofi, G. \& Seikh, A. 2014. The basic rules and methods of mosquito rearing (Aedes aegypti). Tropical Parasitology 4(1): 53-55.

Invest, J.F. \& Lucas, J.R. 2008. Pyriproxyfen as a mosquito larvicide. Proceedings of the $6^{\text {th }}$ International Conference on Urban Pests. pp. 239-245.

Khan, G.Z., Khan, I., Khan, I.A., Alamzeb, Salman, M. \& Ullah, K. 2016. Evaluation of different formulation of IGRs against Aedes albopictus and Culex quinqiefasciatus (Diptera: Culicidae). Asian Pacific Journal of Tropical Biomedicine 6(6): 485-491.

Ladien, J., Souv, K., Leang, R., Huy, R., Cousien, A. \& Peas, M. 2019. An algorithm applied to national surveillance data for the early detection of major dengue outbreaks in Cambodia. PLoS ONE 14(2): e0212003.

Lau, K.W., Chen, C.D., Lee, H.L., Rashid, Y.N. \& Azirun, M.S. 2015. Evaluation of insect growth regulators against fieldcollected Aedes aegypti and Aedes albopictus (Diptera: Culicidae) from Malaysia. Journal of Medical Entomology 52(2): 199-206.

Liang, Y., Mohd Ngesom, A.M., Bahauddin, R., Hidayatul, F.O., Nazni, W.A. \& Lee, H.L. 2019. Modelling the effect of a novel autodissemination trap on the spread of dengue in Shah Alam and Malaysia. Computational and Mathematical Methods 2019: 1923479.

Lindsay, S.W., Wilson, A., Golding, N., Scott, T.W. \& Takken, W. 2017. Improving the built environment in urban areas to control Aedes aegypti borne diseases. Bulletin World Health Organization 95: 607-608.

Llyod, A.M., Farooq, M., Estep, A.S., Xue, R.D. \& Kline, D.L. 2017. Evaluation of pyriproxyfen dissemination via Aedes albopictus from a point-source larvicide application in Northeast Florida. Journal of the American Mosquito Control Association 33(2): 151-155.

Lwetoijera, D., Kiware, S., Okumu, F., Devine, G.J. \& Majambere, S. 2019. Autodissemination of pyriproxyfen suppresses stable populations of Anopheles arabiensis under semi-controlled settings. Malaria Journal 18: 166.

Mains, B.J., Nicholson, J., Winokur, O.C., Steiner, C., Riemersma, K.K. \& Stuart, J. 2018. Vector competence of Aedes aegypti, Culex tarsalis, and Culex quinquefasciatus from California for Zika virus. PLoS Neglected Tropical Diseases 12(6): e0006524.

Maula, A.W., Fuad, A. \& Utarini, A. 2018. Ten-years trend of dengue research in Indonesia and South-east Asian countries: A bibliometric analysis. Global Health Action 11(1): 1504398.

Mbare, O., Lindsay, S.W. \& Fillinger, U. 2014. Pyriproxyfen for mosquito control: Female sterilization or horizontal transfer to oviposition substrates by Anopheles gambiae sensu stricto and Culex quinquefasciatus. Parasites Vectors 7: 280 .

Ngesom, A.M.M., Greenhalgh, D., Lasim, A.M., Sahani, M., Hod, R. \& Othman, H. 2020. A review: Autodissemination of pyriproxyfen as novel strategy to control dengue outbreaks. PERTANIKA Journal Science \& Technology 28(4): 1117 1140.

Norzahira, R., Hidayatulfathi, O., Wong, H.M., Cheryl, A., Firdaus, R. \& Chew, H.S. 2011. Ovitrap surveillance of the dengue vectors, Aedes (Stegomyia) aegypti (L.) and Aedes (stegomyia) albopictus Skuse in selected areas in Bentong, Pahang Malaysia. Tropical Biomedicine 28(1): 48-54.

Ohba, S.Y., Ohashi, K., Pujiyati, E., Higa, Y., Kawada, H., Mito, N. \& Takagi, M. 2013. The effect of pyriproxyfen as "population growth regulator" against Aedes albopictus under semi-field condition. PLoS ONE 8(7): e67045.

Ong, J., Liu, X., Rajarethinam, J., Kok, S.Y., Liang, S. \& Tang, C.S. 2018. Mapping dengue risk in Singapore using random forest. PLoS Neglected Tropical Diseases 12(6): e0006587.

Othman, H., Zul-Izzat, I.K., Norhafizah, K., Nor Azimah, A.R., Muhammad Badrul, H., Mazrura, S., Rozita, H., Saiful Azlan, N. \& Nor Azwani, M.N. 2019. Applying health belief model for the assessment of community knowledge, attitute and prevention practices following a dengue epidemic in a town ship in Selangor, Malaysia. International Journal of Community Medicine and Public Health 6(1): 958-970.

Othman, H., Nordin, S.A., Rashid, N.A., Abas, M.B.H., Hod, R. \& Sahani, M. 2017. Dengue free community as an approach for understanding the value and challenges of inter-agencies partnerships in an intervention program. International Journal of Public Health 4(6): 1810-1826. 
Pang, T., Mak, T.K. \& Gubler, D.J. 2017. Prevention and control of dengue the light at the end of the tunnels. The Lancets Infectious Diseases 17: e79-e87.

Panigrahi, S.K., Barik, T.K., Mohanty, S. \& Tripathi, N.K. 2014. Laboratory evaluation of oviposition behavior of field collected Aedes mosquitoes. Journal of Insects 2014: 207489.

Pleydell, D.R.J. \& Bouyer, J. 2019. Biopesticides improve efficiency of the sterile insect technique for controlling mosquito-driven dengue epidemics. Communications Biology 2(1): $1-11$

Raji, J.I., Nelo, N., Castillo, J.S., Sheyla, G., Saldana, V. \& Stensmyr, M.C. 2019. Aedes aegypti mosquitoes detect acidic volatiles found in human odor using IR8a pathway. Current Biology 29(8): 1253-1262

Rozilawati, H., Zairi, J. \& Adanan, C.R. 2007. Seasonal abundance of Aedes albopictus in selected urban and suburban areas in Penang, Malaysia. Tropical Biomedicine 24(1): 83-94.

Sahani, M., Othman, H., Mohd Nor, N.A., Hod, R., Mohd Ali, Z. \& Rasidi, M.N.M. 2012. Ecology survey on Aedes mosquito in Senawang, Negeri Sembilan. Sains Malaysiana 41(2): $261-269$

Serpa, L.L.N., Marques, G.R.A.M., Lima, A.P., Voltolini, J.C., Arduino, M.B. \& Barbosa, G.L. 2013. Study of the distribution and abundance of the eggs of Aedes aegypti and Aedes albopictus according to the habitat and meteorological variables, municipality of Sao Sebatiao, Sao Paulo State, Brazil. Parasites Vectors 6(1): 1-11.

Sithiprasasna, R., Mahapibul, P., Noigamal, C., Perich, M.J., Zeichner, M.C. \& Burge, B. 2013. Field evaluation of a lethal ovitrap for the control of Aedes aegypti (Diptera: Culicidae) in Thailand. Journal of Medical Entomology 40(4): 455-462.

Smith, E.P., Orvos, D.R. \& Cairns, J. 1993. Impact assessment using the before-after-control-impact (BACI) model: Concern and comments. Canadian Journal of Fisheries and Aquatic Sciences 50(3): 627-637.

Srichan, P., Niyom, S.L., Pacheun, O., Iamsirithawon, S., Chatchen, S., Jones, C., White, L.J. \& Pan-ngum, W. 2018. Addressing challenges faced by insecticide spraying for the control of dengue fever in Bangkok, Thailand: A qualitative approach. International Health 10(5): 349-355.

Stewart-Oaten, A. \& Murdoch, W.W. 1986. Environmental impact assessment: "Pseudoreplication" in time? Ecology 67(4): 929-940.

Suman, D.S., Wang, Y., Faraji, A., William, G.M., Willinges, E. \& Gaugler, R. 2018. Seasonal field efficacy of pyriproxyfen autodissemination stations against container-inhabiting mosquito Aedes albopictus under different habitat conditions. Pest Management Science 74(4): 885-895.

Suman, D.S., Farajollahi, A., Healy, S., Williams, G.M., Wang, Y. \& Schoeler, G. 2014. Point-source and area-wide field studies of pyriproxyfen autodissemination against urban container-inhabiting mosquitoes. Acta Tropica 135(1): 96103.
Suppiah, J., Ching, S.M., Amin-Nordin, S., Mat-Nor, L.A. Ahmad-Najimudin, N.A. \& Low, G.K.K.K. 2018. Clinical manifestations of dengue in relation to dengue serotype and genotype in Malaysia: A retrospective observational study. PLoS Neglected Tropical Diseases 12(9): e0006817.

Suter, T.T., Flacio, E., Farina, B.F., Engeler, L., Tonolla, M. \& Regis, L.N. 2016. Surveillance and control of Aedes albopictus in the Swiss-Italian border region: Differences in egg densities between intervention and non-intervention areas. PLoS Neglected Tropical Diseases 10: e0004315.

Tee, G.H., Yoep, N., Jai, A.N., Abdul Mutalip, M.H., Paiwai, F., Hashim, M.H., Pan, S., Lodz, N.A. \& Aris, T. 2019. Prolonged dengue outbreak at a high-rise apartment in Petaling Jaya, Selangor, Malaysia: A case study. Tropical Biomedicine 36(2): 550-558.

Tokachil, N. \& Yusuf, N. 2018. Effect of rainfall duration on Aedes aegypti populations. AIP Proceedings. p. 020081.

Tuten, H.C., Moosmann, P., Mathis, A. \& Schaffner, F. 2016. Effects of pyriproxyfen on Aedes japonicus development and its autodissemination by gravid female in laboratory trials. Journal of the American Mosquito Control 32(1): $55-58$.

Unlu, I., Rochlin, L., Suman, D.S., Wang, Y., Chandel, K. \& Gaugler, R. 2020. Large-scale operational pyriproxyfen autodissemination deployment to suppress the immature asian tiger mosquito (Diptera: culicidae) populations. Journal of Medical Entomology 57(4): 1120-1130.

Unlu, I., Suman, D.S., Wang, Y., Klingler, K., Faraji, A. \& Gaugler, R. 2017. Effectiveness of autodissemination stations containing pyriproxyfen in reducing immature Aedes albopictus populations. Parasites Vectors 10(1): $1-10$.

Valdez, L.D., Sibona, G.J. \& Condat, C.A. 2018. Impact of rainfall on Aedes aegypti populations. Ecological Modelling 385(1): 96-105

Vector Diseases Branch (VBD). 2005. Protocol for Surveilance and Monitoring of Vector using Ovitrap. Putrajaya: Division of Disease Control, Ministry of Health.

Withanage, G.P., Hapuarachchi, H.C., Viswakula, S.D., Gunawardena, Y.I.N.S. \& Hapugoda, M. 2020. Entomological surveillance with viral tracking demonstrates a migrated viral strain caused dengue epidemic in July, 2017 in Sri Lanka. PLoS ONE 15(5): e0231408.

World Health Organization (WHO). 2020. Dengue and Severe Dengue. https:/www.who.int/news-room/fact-sheets/detail/ dengue-and-severe-dengue. Assessed on 25 March 2020.

World Health Organization (WHO). 2016. Monitoring and Managing Insecticide Resistance in Aedes Mosquito Populations: Interim Guidance for Entomologists.. https:// apps.who.int/iris/handle/10665/204588. Assessed on 8 March 2016.

Yazan, L.S., Paskaran, K., Gopalsamy, B. \& Majid, R.A. 2020. Aedestech Mosquito Home System prevents the hatch of Aedes mosquito eggs and reduces its population. PERTANIKA Journal of Science \& Technology 28(1): 263278 
Zapletal, J., Erraguntla, M., Adelman, Z.N., Myles, K.M. \& Lawley, M.A. 2018. Impacts of diurnal temperature and larval density on aquatic development of Aedes aegypti. PLOS ONE 13: 0194025.

Zul-'Izzat, I.Z., Hidayatulfathi, O., Norhafizah, K., Nor Azimah, A.R., Mohamad Badrul, H.A., Mazrura, S., Rozita, H. \& Saiful Azlan, N. 2019. Knowledge and practices regarding Aedes control amongst residents of dengue hotspot areas in Selangor: A cross-sectional study. Sains Malaysiana 48(4): 841-849.

Ahmad Mohiddin Mohd Ngesom, Mazrura Sahani \& Hidayatulfathi Othman*

Faculty of Health Sciences

Universiti Kebangsaan Malaysia

Jalan Raja Muda Abdul Aziz

50300 Kuala Lumpur, Federal Territory

Malaysia

Nazni Wasi Ahmad \& Lee Han Lim

Medical Entomology Unit

Institute for Medical Research

Jalan Pahang

50588 Kuala Lumpur, Federal Territory

Malaysia
Asmalia Md Lasim

Faculty of Science and Technology

Universiti Kebangsaan Malaysia

43600 UKM Bangi, Selangor Darul Ehsan

Malaysia

David Greenhalgh

Department of Mathematics and Statistics

University of Strathclyde

16, Richmond Street

Glasgow, G11XQ

United Kingdom

Rozita Hod

Department of Community Health, Faculty of Medicine

Universiti Kebangsaan Malaysia

Jalan Yaacob Latif, Bandar Tun Razak

56000 Cheras, Kuala Lumpur, Federal Territory

Malaysia

*Corresponding author; email: hida@ukm.edu.my

Received: 30 March 2020

Accepted: 31 December 2020 